\title{
Design and Performance Analysis of a Latent Heat Storage for the Operation of a High-Temperature Methanol Fuel Cell
}

\author{
Lisa Deinert \\ Renewable Energy \\ Fraunhofer Institute for Environmental, \\ Safety, and Energy Technology \\ UMSICHT \\ Sulzbach-Rosenberg, Germany \\ lisa.deinert@umsicht.fraunhofer.de
}

\author{
Robert Daschner \\ Renewable Energy \\ Fraunhofer Institute for Environmental, \\ Safety, and Energy Technology \\ UMSICHT \\ Sulzbach-Rosenberg, Germany \\ robert.daschner@umsicht.fraunhofer.de
}

\author{
Andreas Hornung \\ Friedrich-Alexander University \\ Erlangen-Nuremberg (FAU) \\ University of Birmingham \\ Fraunhofer Institute for Environmental, \\ Safety, and Energy Technology \\ UMSICHT \\ Sulzbach-Rosenberg, Germany \\ andreas.hornung@umsicht.fraunhofer.d
}

\begin{abstract}
Due to ever stricter economical and legislative regulations, the efficiency of technical processes has to be constantly increased. Besides many other efficiency enhancing methods, the use of waste heat has a great potential to save energy. In particular, the use of waste heat at temperatures above $373 \mathrm{~K}$ offers many possibilities, as it is mostly unused today. In order to exploit these potentials, a new latent heat storage system using a polymer as a phase change material has been developed during the $R \& D$ project "eleMeMe Decentralized decoupling of power generation and energy supply through onsite electrochemical methanol production and methanol fuel cells". The storage is used to operate a hightemperature methanol fuel cell. Usually the fuel cell must be electrically preheated before the start to reach its optimum operating temperature. During operation, heat is generated and the system has to be air cooled to maintain its temperature. Instead of cooling the system with air, the heat is now stored in a latent heat storage system to start the fuel cell later.
\end{abstract}

Keywords-latent heat storage, flexibilization, phase change material, polymers, $\mathrm{HDPE}$

\section{INTRODUCTION}

One of the biggest challenges in modern society is to control manmade pollution in order to limit the damages to the environment and climate. Therefore, legal regulations as well as limited fossil fuel resources force us to reduce our energy consumption or to use renewable energy. Besides investing in new processes and applications, a way to limit the energy demand is to enhance the energy efficiency of existing processes. Energy storage systems are among the possibilities suitable for this purpose. Storages also help to bridge time discrepancies between energy generation and consumption, which is often a problem when using renewable energy. In particular, the use of thermal energy storages has a high potential since only a part of the existing excess heat is reasonably used today. Thermal energy storages enable us to save energy and thus reduce $\mathrm{CO}_{2}$ emissions by improving our demand side management and load shifting. Whereas sensible

This work is funded by the German Federal Ministry for Economic Affairs and Energy. water storages are already state of the art, latent heat storages are mostly still under development. Applications with temperatures above $373 \mathrm{~K}$ are especially interesting for latent heat storage due to their high energy density and much lower pressure level than pressurized water storages.

\section{A. State of the art technology}

In the temperature range between $373 \mathrm{~K}$ and $523 \mathrm{~K}$, a lot of storage materials have been examined and developed. Possible phase change materials (PCM) are salt hydrates, paraffins, polyethylene glycols, sugar alcohols and nitrates [1]. Salt hydrates and nitrates are inorganic chemicals. Salt hydrates in particular are often used as PCM, even though they often have many disadvantages like phase segregation [2], super cooling [3] and corrosion with commonly used metals [4]. Nitrates and their eutectic mixtures are used when a melting temperature between $423 \mathrm{~K}$ and $623 \mathrm{~K}$ is needed. One of their major disadvantages is their poor thermal conductivity [5]. Most organic phase change materials also have low thermal conductivity [6], but some have a high enthalpy of fusion, a low price and high stability. Promising materials are for example fatty acids [7], sugar alcohols [8], carboxylic acids [9], amides [10], paraffins [11] or polymers [12, 13].

Although polymers also suffer from low thermal conductivity, they have many advantages. Polymers have mostly been investigated as form-stable PCM [14] or as encapsulation material [15]. Very few publications focus on their use as storage materials $[13,16,17]$ even though they offer very interesting properties for the use as PCM. Most plastics are produced on a large industrial scale, which leads to a high availability and thus low prices for common plastics. Additionally, plastics are well known and studied, and their properties can be adjusted by additives. Different processing techniques can be used to produce different shapes of the PCM, which may be interesting for form-stable PCM. Many polymers can be produced from renewable sources and can be recycled, which reduces the material costs and is beneficial for sustainability [13]. One especially interesting polymer is high density polyethylene (HDPE), since it has some major characteristics necessary for storage materials: a high enthalpy of fusion, low-cost and high stability in molten state. 
Unfortunately, its thermal conductivity is low, which is compensated through improved materials or storage design [18]. Reference [13] built a demonstrator using HDPE as a storage material and aluminum alloy fins on the heat exchanger to overcome limitations through thermal conductivity. This publication shows the feasibility, functionality and stability of a HDPE storage.

In this temperature region there are many possible applications for thermal energy storages. A lot of research has been done in the field of solar energy [17, 19, 20,21], but there are also applications of waste heat recovery, such as in the chemical industry [22] or from engine exhaust gases [23]. There are also examples for the use of latent heat storages in combinations with fuel cells [24].

Thermal storages are often highly dependent on their application. The novel latent heat storage presented here uses the advantages of HDPE and overcomes the low thermal conductivity by its storage design. The latent heat storage is designed to use the waste heat of a high-temperature methanol fuel cell. The waste heat is stored during the operation of the fuel cell and is used to preheat the fuel cell.

\section{B. Project description}

In the project "eleMeMe - Decentralized decoupling of power generation and energy supply through onsite electrochemical methanol production and methanol fuel cells", it is shown how the coupling of different energy storage methods can be used to decouple the power generation and the power consumption. This project is carried out by Fraunhofer UMSICHT, Fraunhofer IGB and Siqens $\mathrm{GmbH}$ and funded by the German Federal Ministry for Economic Affairs and Energy. To dampen the fluctuation of renewable power generation, the excess power is used for electrochemical methanol production. The methanol is then stored and thus it serves as a storage system. To generate electricity, the methanol is used to operate a high-temperature methanol fuel cell from Siqens $\mathrm{GmbH}$. The $\mathrm{CO}_{2}$ produced in the fuel cell is captured in a $\mathrm{CO}_{2}$ storage tank and is reused to produce methanol. The methanol and the $\mathrm{CO}_{2}$ are circulated in a closed system. A novel latent heat storage system is used to improve the heat management of the high-temperature methanol fuel cell. During regular operation, the fuel cell is cooled by air to ensure the optimum operating temperature of $433 \mathrm{~K}$. This generates a large amount of waste heat, which is especially frustrating since the fuel cell has to be electrically heated for start up. This issue can be overcome by our thermal energy storage. The waste heat during the operation is stored in the latent heat storage and later used to restart the fuel cell after it has been shut down. The energy which remains in the storage after the fuel cell is started can be used either to heat up the $\mathrm{CO}_{2}$ storage tank to its desorption temperature (release temperature of the $\mathrm{CO}_{2}$ ) or in domestic applications.

The fuel cell is modified from air cooling to a liquid cooling system. An oil based cooling system is an important step to guarantee the heat transfer between the two systems. Two heat transfer plates were attached to the fuel cell stack to generate a closed circle for the heat transfer fluid (HTF). The waste heat generated by the fuel cell has a temperature of $433 \mathrm{~K}$ and can be used to charge the storage. Since the fuel cell is in operation over a long time span, hours or even days, the loading of the storage is not the critical part of the design. The critical part is the discharge of the storage. To start the fuel cell, it needs approximately $1.05 \mathrm{~kW}$ and temperatures over $373 \mathrm{~K}$ for a time span of 1800 to 3600 seconds.

\section{EXPERIMENTAL SET UP}

\section{A. HDPE as phase change material}

To meet all the requirements listed above, a PCM has to be chosen based on its melting temperature being within the operating temperature of the high-temperature methanol fuel cell. After a thorough screening of the literature, HDPE was selected because it has a high enthalpy and a suitable melting temperature. Furthermore, it is easy to handle, non-toxic, cheap and readily available. The material used is HDPE M80064 from sabic ${ }^{\circledR}$. It has been analyzed in the differential scanning calorimeter (DSC) to confirm its melting temperature $\mathrm{T}$ as $403.33 \mathrm{~K}$ and its enthalpy of fusion $\mathrm{h}$ as 209.27 $\mathrm{J}^{*} \mathrm{~g}^{-1}$. The data can be seen in TABLE I, together with the data of the crystallization process. It is clearly visible that HDPE only shows a supercooling of about $10 \mathrm{~K}$.

TABLE I. MATERIAL PROPERTIES OF HDPE MEASURED BY DSC.

\begin{tabular}{|c|c|c|}
\hline & \multicolumn{2}{|c|}{ Material properties } \\
\hline & $\begin{array}{c}T \\
(K) \\
\end{array}$ & $\begin{array}{c}h \\
(\mathrm{~J} / \mathrm{g}) \\
\end{array}$ \\
\hline melt & 403.33 & 209.27 \\
\hline crystallization & 393.43 & 203.52 \\
\hline
\end{tabular}

\section{B. Latent heat storage design}

The heat storage is designed to have a cylindrical shape to prevent dead room. The cylindrical shape of the shell and the round bottom of the storage avoid corners to use the full potential of the PCM. The storage tank has a height of $0.550 \mathrm{~m}$ and an inner diameter of $0.396 \mathrm{~m}$. The shell is made of stainless steel 1.4301 and has a thickness of $0.005 \mathrm{~m}$. Inside the storage there are two registers of $20 \mathrm{~m}$ long pipes. The pipes are connected in parallel and are designed as corrugated tubes to enhance the heat transfer from the PCM to the heat transfer fluid and vice versa. The tubes are widely corrugated and are made of the stainless steel 1.4404. They have an outer diameter of $0.0165 \mathrm{~m}$ and an inner diameter of $0.0145 \mathrm{~m}$. The shape of the surface is intended to ensure a turbulent flow even at low flow velocities, thus enhancing the heat transfer. Besides the larger surface area of the corrugated pipes, the biggest advantage is their flexibility and small bending radius. The flexibility of the tubes is used to compensate for the tension built up during the volume change at the phase change. HDPE has a very low thermal conductivity, which makes heat transfer through the PCM a problem. In this design, a distance of $0.022 \mathrm{~m}$ between the pipes has been chosen to avoid limitations through heat transfer. The tubes run through the storage from top to bottom, using the minimal bending radius of $0.02 \mathrm{~m}$ for the $180^{\circ}$ turns every $0.47 \mathrm{~m}$. The two registers are symmetrical and each fill one half of the storage. The storage has two inputs and two outputs, which can be switched according to the process requirements and are shown in fig. 1. To charge the storage, the fluid enters through the inner connections in the tank and moves out through the inner semicircle. To discharge the storage, the fluid enters through the outer connections and gradually moves inwards. 

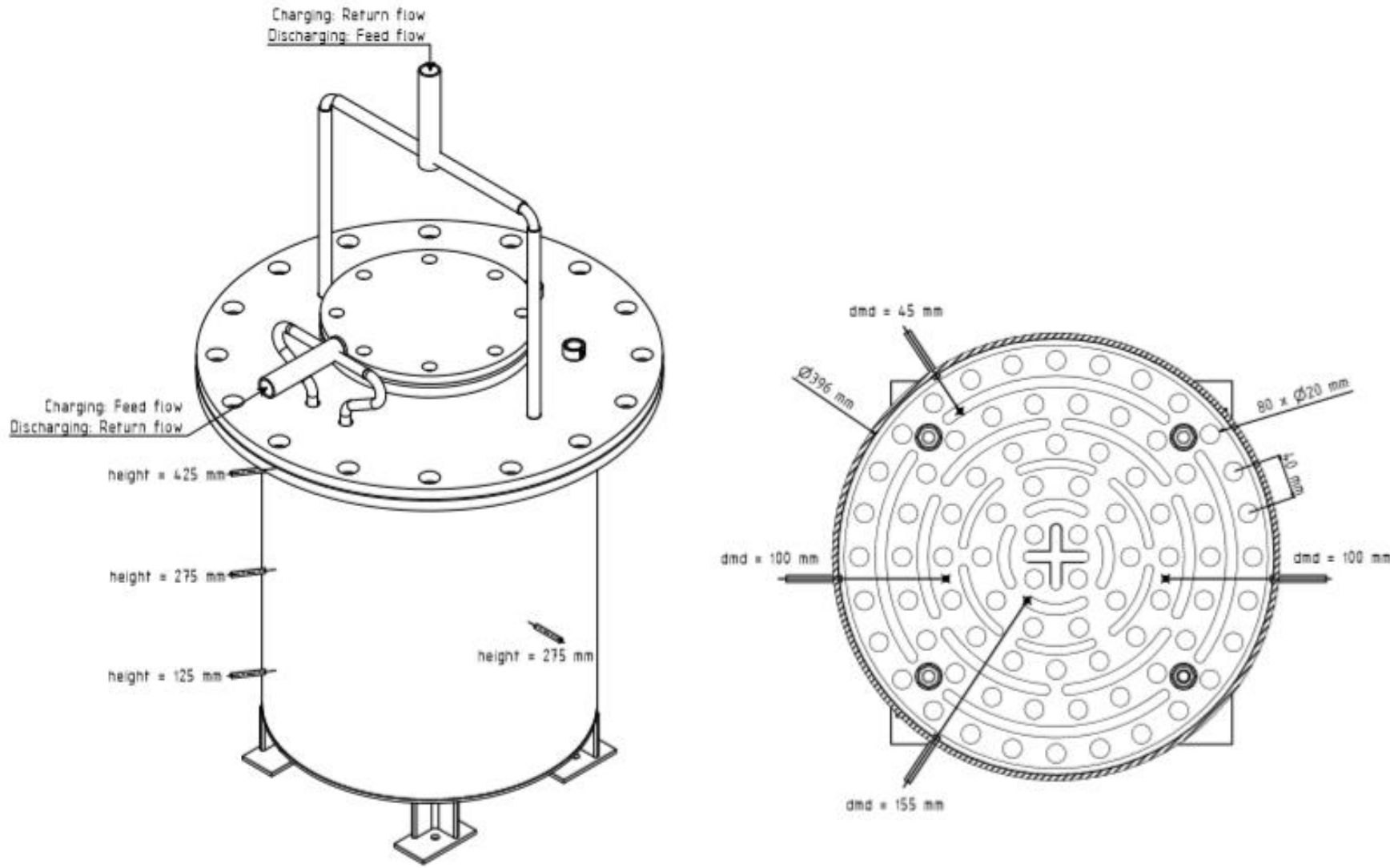

Fig. 1. Technical drawing of the storage including entrance and exit (left) and top view of the storage with the guiding plate for the corrugated pipes as well as the connections for the thermocouples and depth in the PCM (dmd).

The storage tank contains ten thermocouples of type $\mathrm{K}$, which are indirectly inserted into the PCM at three different heights (height $=125,275$ and $425 \mathrm{~mm}$ ) and depths ( $\mathrm{dmd}=45,100$ and $155 \mathrm{~mm}$ ) to provide an overview of the storage performance. With the help of a simulation the principle of this design can be shown and verified. In fig 2 . you can see the qualitative heat distribution during the discharge of the storage. As the fluid enters in the outer circle with a HTF temperature of $293.15 \mathrm{~K}$, the fluid gradually gains temperature until it reaches its full temperature in the middle of the storage.
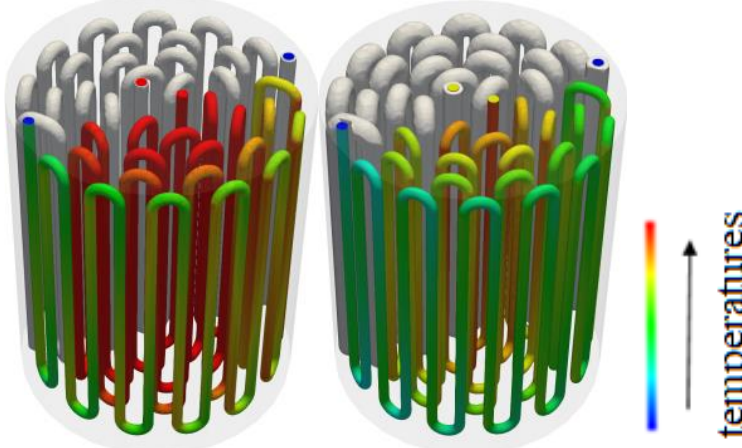

$$
\mathrm{t}=60 \mathrm{~s}
$$$$
\mathrm{t}=600 \mathrm{~s}
$$

Fig. 2. Results of the CFD simulation showing the heat distribution of the heat transfer fluid in the latent heat storage tank and the uniform solidification of the phase change material around the pipes.
This design makes it possible to increase the amount of energy extracted from the storage tank, as the loss to the environment can be minimized.As the outer part of the storage is being cooled down first and is therefore the first part to crystallize, the HDPE insulates the still liquid part in the middle of the storage. On the wall of the pipes, the PCM starts to crystallize by building a shell around the pipes, which gradually grows until the PCM is completely solidified. As can be seen in fig. 2, the layer is growing evenly around the pipes.

To minimize heat loss to the environment, the insulation Rockwool ProRox PS 960 with a strength of $0.1 \mathrm{~m}$ is used. The total weight of the storage is $159 \mathrm{~kg}$ with $42 \mathrm{~kg}$ of HDPE. The latent heat storable in the phase change is $2.4 \mathrm{kWh}$, which is the maximum amount of energy needed to start the fuel cell. An important part of avoiding dead space and utilizing the full potential of the storage is a complete filling of the storage. To ensure proper filling, the HDPE pellets had to be filled in uniformly, as the melt of the HDPE is highly viscous and it's not possible to fill the HDPE in in liquid state. After the first filling, the storage is heated to $433 \mathrm{~K}$ and the temperature is held overnight. Through this procedure, the melt can flow in the empty spaces and gas bubbles have time to move to the surface. After that procedure, the surface of the HDPE sinks significantly and the empty space is filled with HDPE. This procedure is continued until the desired mass of $42 \mathrm{~kg}$ is inside the storage and the pipes are fully covered with HDPE. The physical properties of the main components can be seen in TABLE II. 
TABLE II.

OVERVIEW OF THE MATERIAL PROPERTIES HEAT CONDUCTIVITY, DENSITY AND SPECIFIC HEAT CAPACITY AT $293.15 \mathrm{~K}$.

\begin{tabular}{|c|c|c|c|c|}
\hline \multirow[b]{2}{*}{ Material } & \multicolumn{3}{|c|}{ Material properties } & \multirow[b]{2}{*}{ Source } \\
\hline & $\begin{array}{c}\lambda \\
(W / m K)\end{array}$ & $\begin{array}{c}\rho \\
\left(\mathrm{g} / \mathrm{cm}^{3}\right)\end{array}$ & $\begin{array}{c}c_{p} \\
(\mathrm{~J} / \mathrm{kg} \mathrm{K})\end{array}$ & \\
\hline HDPE & 0.48 & $\begin{array}{c}0.94- \\
0.97\end{array}$ & 2.60 & {$[6]$} \\
\hline $\begin{array}{l}\text { Silicon oil } \\
\text { M20.235/195.20 }\end{array}$ & 0.151 & 0.95 & 45.75 & [25] \\
\hline $\begin{array}{l}\text { Corrugated pipes } \\
1.4404\end{array}$ & 15 & 8 & 500 & [26] \\
\hline $\begin{array}{ll}\text { Storage } & \text { shell } \\
1.4301 & \end{array}$ & 15 & 7.9 & 500 & [27] \\
\hline $\begin{array}{l}\text { Rockwool ProRox } \\
\text { PS } 960\end{array}$ & 0.0387 & $>0.1$ & - & [28] \\
\hline
\end{tabular}

\section{Set up of the test rig}

In fig. 3 the experimental setup of the test rig, including the latent heat storage, is depicted. On the right, the cylindrical storage (d) is shown. The volume change caused by the phase change of the HDPE can build up pressure in a closed system. To prevent this, two valves, one pressure relief valve and one check valve, were installed together with a pressure sensor. The rest of the measurement technology is installed in the HTF circuit. In the HTF stream, temperature and pressure sensors are located at the entry and the exit of the storage as well as at the entry and the exit of the fuel cell connection (b). Additionally, there are volume flow meters in the feed and in the return flow.

On the left side next to the aluminum frame the thermostat (a) can be seen, which represents both the heat source and the heat sink for the experiments without the fuel cell. The thermostat (Huber Unistat 425) has a heating power of $12 \mathrm{~kW}$ and a cooling power of $2.5 \mathrm{~kW}$. The HTF used for the experiments was the silicon oil M20.235/195.20 from Huber Kältemaschinen GmbH. From the thermostat (a) the HTF flows through the connections for the fuel cell (b) to a second pump (c, Huber Unipump) and to the storage (d). As mentioned above, the entry and exit of the storage can be switched by a four-way valve. After the storage tank, the fluid flows back to the thermostat. The test rig contains three bypasses (I, II and III) in total. One bypass (III) to exclude the storage, one (I) to exclude the thermostat and one (II) to regulate the pressure and the volume flow. This piping system makes it possible to preheat or cool the circle before entering the storage to guarantee equal conditions when entering the heat storage.

To charge the heat storage, the HTF is at ambient temperature and is heated by the thermostat at maximum power. The HTF flows through the outer circle and directly through the storage tank by entering it in the middle. After the desired temperature of the storage is reached, the storage is excluded from the circuit via bypass (III). The fluid in this cycle is cooled to $293.15 \mathrm{~K}$ to simulate the start of the fuel cell at ambient temperature. After reaching the temperature, the storage is again connected with the cycle and the cold HTF can enter the storage at the outer connections. The thermostat now acts as the heat sink and cools the HTF with a defined power. During the experiments with the fuel cell, the thermostat is responsible for volume flow control but no longer heats or cools the system. The heat source is the waste heat of the fuel cell during operation and the heat sink is the cold fuel cell before start.

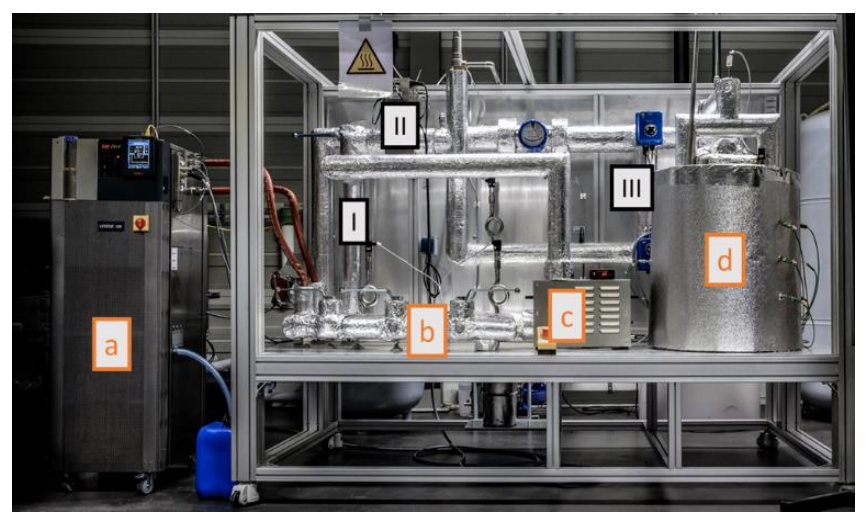

Fig. 3. Picture of the test rig with the thermostat (a), the fuel cell connections (b), the pump (c) and the latent heat storage (d), as well as the bypasses (I, II and III).

\section{RESULTS AND DISCUSSION}

\section{A. Experimental methodology}

To define the best operation point, we conducted a number of experiments to characterize the storage. Since the charge of the storage takes place during operation of the fuel cell, this is not the most time sensitive step. The maximum temperature that can be supplied by the fuel cell is $433.15 \mathrm{~K}$. This has been defined as the maximum storage temperature, as it is known that it will most likely be at a lower level due to heat loss to the environment. The minimum temperature of the storage is defined by the PCM. In the DSC measurements, a minimum temperature of $403.33 \mathrm{~K}$ was determined as the melting temperature. The minimum storage temperature was set to $413.15 \mathrm{~K}$ to ensure that it is above the melting point. In previous calculations, it was found that the fluid flow must be $0.36 \mathrm{~m}^{3 *} \mathrm{~h}^{-1}$ or lower to achieve the best results for discharging the storage. Since $0.12 \mathrm{~m}^{3 *} \mathrm{~h}^{-1}$ is the minimum volume flow that can stably pass through the test rig using the thermostat as a controlling instrument, this was set as the lower limit. The final variable was the cooling capacity of the thermostat, which represents the heat sink. The capacity was varied from $2.5 \mathrm{~kW}$ to $1 \mathrm{~kW}$ since it is highly unlikely that the fuel cell will be able to have a higher cooling power than $2.5 \mathrm{~kW}$. Each experiment started at room temperature and contains the charging and the discharging process of the storage.

As shown in fig. 4, each experiment can be structured into three parts. The charge (I), the preparation for discharge (II) and the discharge (III). The storage is considered fully charged when the average temperature of all ten temperature sensors inside the PCM is the desired storage temperature, in this case $433 \mathrm{~K}$. Part II is used to cool the HTF in the piping system to 293.15 K in order to simulate the start of the fuel cell at room temperature. This procedure ensures the same starting conditions for the discharging process for all the experiments. After the preparation phase, the discharging starts in part III. The end of this phase is reached as soon as all the temperature sensors reach $293.15 \mathrm{~K}$ again. 


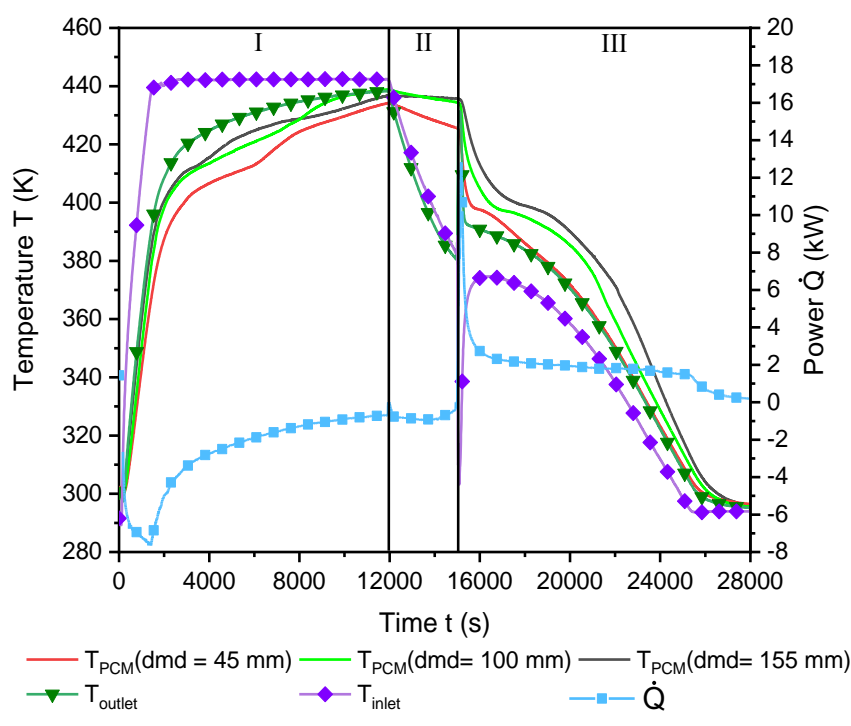

Fig. 4.

Temperature and power profile for a storage temperature of $433 \mathrm{~K}$ and a volume flow of $0.36 \mathrm{~m}^{3 *} \mathrm{~h}^{-1}$. The cooling capacity of the thermostat is set to $2.5 \mathrm{~kW}$.

\section{B. Results}

For this experiment (fig. 4), the final storage temperature was set to $433 \mathrm{~K}$, the volume flow to $0.36 \mathrm{~m}^{3 *} \mathrm{~h}^{-1}$ and the cooling capacity to $2.5 \mathrm{~kW}$. As can be seen in fig. 4 , the HTF enters the storage with a constant temperature of $443 \mathrm{~K}$ after a starting phase of $1500 \mathrm{~s}$. Due to the design of the storage and the flow path of the HTF, the PCM first melts in the middle of the storage $\mathrm{T}_{\mathrm{PCM}}(\mathrm{dmd}=155 \mathrm{~mm})$, followed quickly by the PCM at dmd $=100 \mathrm{~mm}$. The outer part of the PCM $\mathrm{T}_{\mathrm{PCM}}(\mathrm{dmd}=45 \mathrm{~mm})$ takes the longest time to melt. Since the HTF enters in the middle, it has already transferred part of its heat to the inner part of the PCM, so the temperature difference, and thus the driving force, is lower at this point. Additionally, the heat loss to the environment is greatest at the outer part. For the discharge, the outer part cools down faster. The longer the discharge process takes, the more similar the temperatures become. Since the cold fluid enters at the outer part it is obvious that it also cools down the fastest. The outer part crystallizes a lot faster than the inner regions, and the temperature in the inner regions is more uniform. This proves the desired effect of the self isolation of the PCM by the outer shell. Due to the inlet temperature of $293.15 \mathrm{~K}$, there is a high power peak at the beginning of the discharging process, which quickly stagnates to an average power of $2 \mathrm{~kW}$. In this experiment, the temperature of the HTF exiting the storage stayed over $373 \mathrm{~K}$ for $4700 \mathrm{~s}$.

The temperature distribution in the storage is also shown in fig. 4. It can be seen that all the temperature sensors have a similar course and show the plateau which is typical for latent heat storages, which is caused by the phase change. It can therefore be assumed that the storage is completely crystallized after discharging. As the cold HTF is entering at the outer shell for discharging, the temperatures at $\mathrm{dmd}=45 \mathrm{~mm}$ start to drop at first and a larger gradient can be seen. At the $d m d=155 \mathrm{~mm}$ the discharging starts about 120 seconds later which corresponds to the residence time. Since the HTF has already transferred part of its heat to the outer PCM the driving force is slower and therefore the temperature of the PCM stays high for a longer time.

To characterize the charging behavior of the storage, three different volume flows $\left(0.12,0.24\right.$ and $\left.0.36 \mathrm{~m}^{3 *} \mathrm{~h}^{-1}\right)$ and three different storage temperatures ( $413 \mathrm{~K}, 423 \mathrm{~K}$ and $433 \mathrm{~K}$ ) were tested. In fig. 5, the storage temperature of $433 \mathrm{~K}$ is depicted at volume flows of 0.12 and $0.36 \mathrm{~m}^{3 *} \mathrm{~h}^{-1}$.

While the charging with a HTF flow of $0.36 \mathrm{~m}^{3 *} \mathrm{~h}^{-1}$ only takes $12000 \mathrm{~s}$ to complete, the slower volume flow needs $17000 \mathrm{~s}$ to heat up the storage completely. Due to the design of the storage with its $20 \mathrm{~m}$ long pipes, the residence time of the HTF is long enough to transfer the heat to the PCM even at higher fluid flows. The limiting step therefore is not the heat transfer from the liquid to the PCM. At $0.12 \mathrm{~m}^{3 *} \mathrm{~h}^{-1}$, the HTF transfers the heat to the PCM before reaching the end of the storage. Hence, the volume flow is too slow for optimum operation. At higher volume flows, the charging of the storage is a lot more effective.

The critical step of a latent heat storage is the discharging process, since it has to be specially adapted to the application and is the most time sensitive. The goal in our application is to keep the temperature above $373 \mathrm{~K}$ as long as possible with a minimum of one hour. Fig. 6 shows the comparison between a storage temperature of $433 \mathrm{~K}$ and $413 \mathrm{~K}$ as well as a cooling capacity of $1 \mathrm{~kW}$ and $2.5 \mathrm{~kW}$ at $0.12 \mathrm{~m}^{3 *} \mathrm{~h}^{-1}$. It can be seen that the storage temperature has only a minor influence on the outlet temperature, as long as it is above the melting temperature. With a cooling power of $2.5 \mathrm{~kW}$, the temperature of $433 \mathrm{~K}$ only prolonged the time over $373 \mathrm{~K}$ by $900 \mathrm{~s}$ compared to a storage temperature of $413 \mathrm{~K}$. At a power of $1 \mathrm{~kW}$, this time was more than doubled to $1900 \mathrm{~s}$. The most effective way to keep the heat up for a longer time is to reduce the cooling capacity of the thermostat. By reducing the capacity, the time above $373 \mathrm{~K}$ at a storage temperature of $433 \mathrm{~K}$ can be increased from $4300 \mathrm{~s}$ to $9000 \mathrm{~s}$ and at $413 \mathrm{~K}$ from $3400 \mathrm{~s}$ to $7100 \mathrm{~s}$. In both experiments the time above $373 \mathrm{~K}$ could be doubled. Fig. 7 illustrates the corresponding power to fig. 6 .

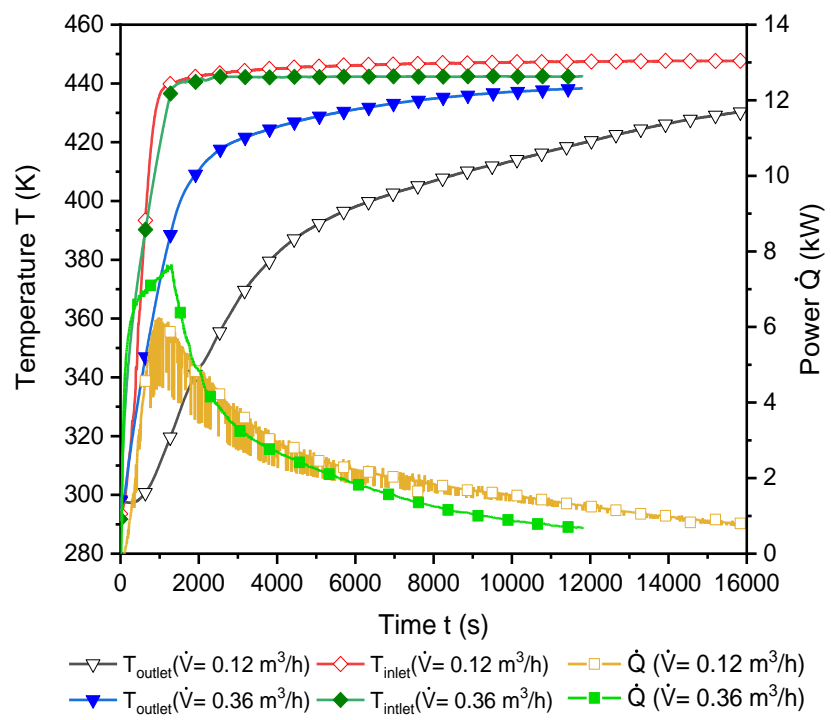

Fig. 5. Temperature and power profile of the charge of the latent heat storage to $433 \mathrm{~K}$ and two different volume flows $\left(0.12\right.$ and $\left.0.36 \mathrm{~m}^{3 *} \mathrm{~h}^{-1}\right)$ 


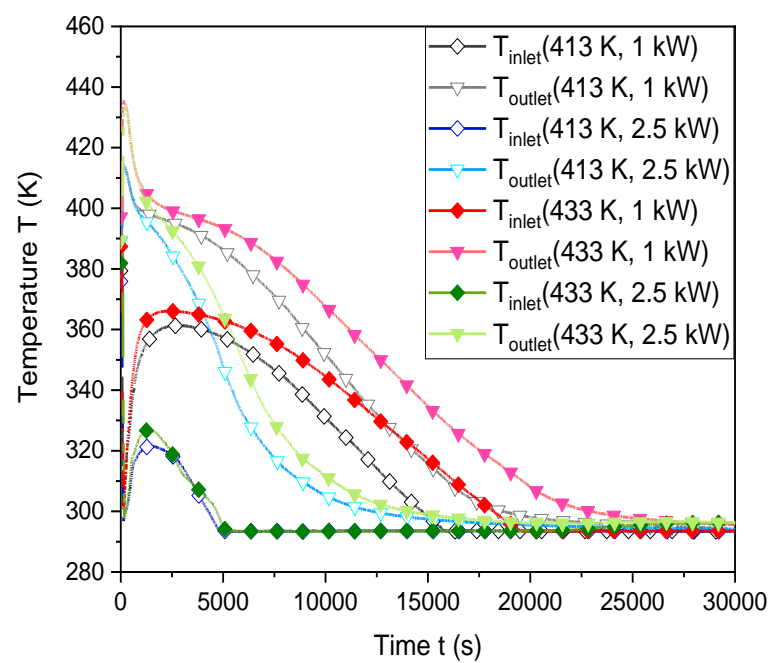

Fig. 6. Temperature profile during the discharging process from two different storage temperatures $(413 \mathrm{~K}, 433 \mathrm{~K})$ and cooling capacities $(1 \mathrm{~kW}, 2 \mathrm{~kW})$.

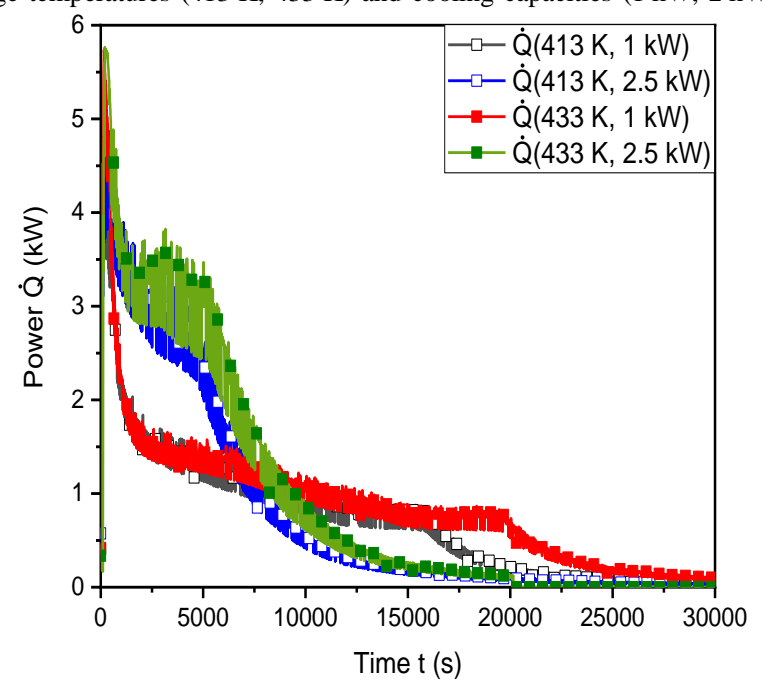

Fig. 7. Power profile during the discharging process from two different storage temperatures $(413 \mathrm{~K}, 433 \mathrm{~K})$ and cooling capacities $(1 \mathrm{~kW}, 2 \mathrm{~kW})$.

Each graph shows the typical plateau for latent heat storages. When the cooling capacity of the thermostat is set to a maximum of $2.5 \mathrm{~kW}$, the output power of the plateau is between 3 and $3.5 \mathrm{~kW}$. This high output can only be maintained for about $6000 \mathrm{~s}$. Reducing the cooling capacity extends this plateau to roughly $18000 \mathrm{~s}$. In this way, we can guarantee an even power output of around $1 \mathrm{~kW}$.

Either way, both experiments show that we reach the desired goals of one hour above $373 \mathrm{~K}$ and over $1.05 \mathrm{~kW}$ power output. In order to identify the influence of the HTF volume flow on the storage system, a series of experiments were carried out. In fig. 8 the results of the experiments with $433 \mathrm{~K}$ storage temperature, $1 \mathrm{~kW}$ cooling capacity and the variation of the volume flow of 0.12 and $0.36 \mathrm{~m}^{3 *} \mathrm{~h}^{-1}$ are presented. The best results can be seen for the experiment with $0.12 \mathrm{~m}^{3 *} \mathrm{~h}^{-1}$. The temperature drops to the crystallization temperature in about $1800 \mathrm{~s}$ and remains above $393 \mathrm{~K}$ for the next $3300 \mathrm{~s}$. After another $4200 \mathrm{~s}$, the temperature reaches 373 K. In total it takes $9300 \mathrm{~s}$ to reach $373 \mathrm{~K}$.

At higher volume flows $\left(0.36 \mathrm{~m}^{3 *} \mathrm{~h}^{-1}\right)$, the temperature drops much faster. $393 \mathrm{~K}$ is reached in only $900 \mathrm{~s}$ and although the typical even temperature profile is seen around the melting point, it is much shorter.

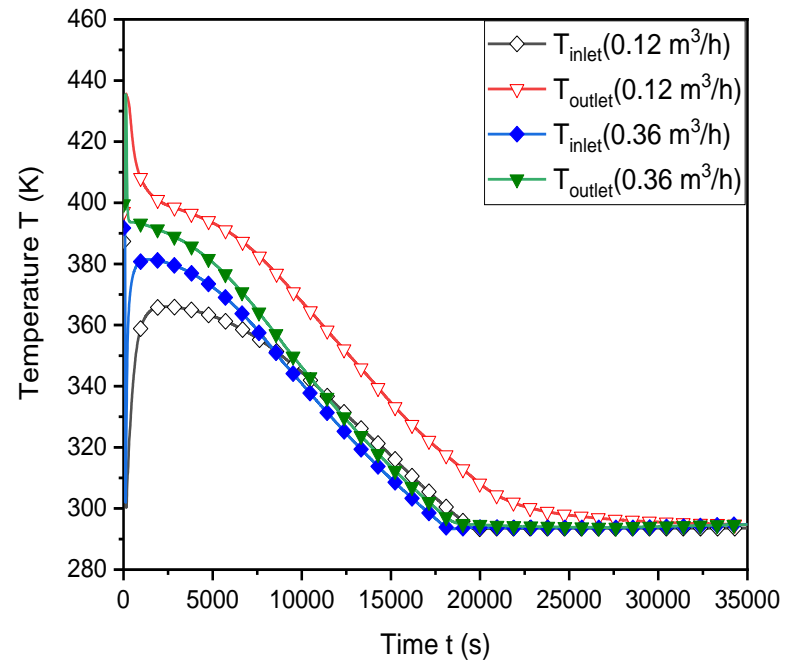

Fig. 8. Temperature profiles of a volume flow variation from 0.12 to $0.36 \mathrm{~m}^{3} * \mathrm{~h}^{-1}$ at storage temperature of $433 \mathrm{~K}$ and $1 \mathrm{~kW}$ cooling capacity at discharge.

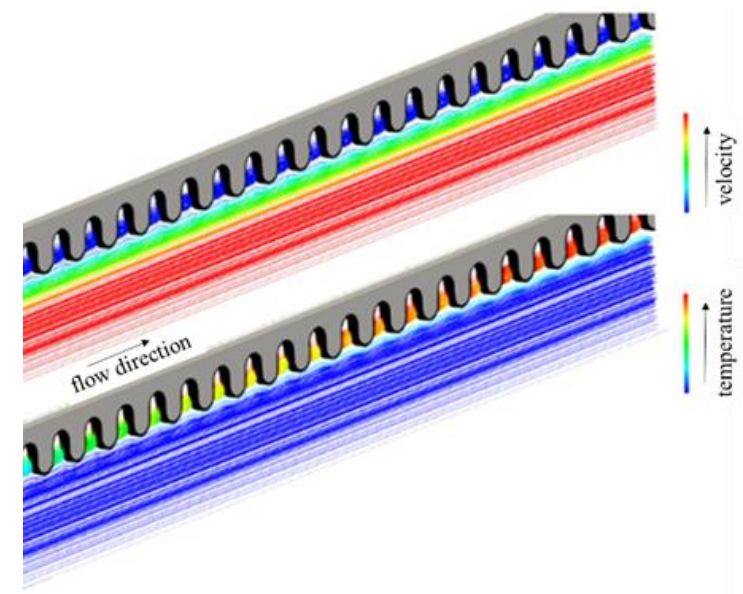

Fig. 9. Velocity and temperature during discharge with a volume flow of $0.40 \mathrm{~m}^{3 *} \mathrm{~h}^{-1}$.

The limit of $373 \mathrm{~K}$ is reached after $6300 \mathrm{~s}$. One reason for this result is the shape of the corrugated pipes used for heat exchange. As can be seen in the simulation (fig. 9), flow nests with high temperature and low flow velocities can build up in the write-offs of the pipes. At high fluid flows, the stream isn't mixed properly and the heat doesn't fully reach the main flow. This effect explains the rapid heat drop at higher flow rates. At $0.12 \mathrm{~m}^{3 *} \mathrm{~h}^{-1}$ the temperature difference between the entering and exiting fluid is much greater than at $0.36 \mathrm{~m}^{3 *} \mathrm{~h}^{-1}$. This leads to a higher driving force between HFT and PCM and hence to a better heat transfer. At high flow rates the residence time of the storage is much shorter and therefore the time for the heat transfer is the limiting step.

\section{Conclusion}

The experiments shown demonstrate the suitability of the designed storage for the operation of a high temperature methanol fuel cell. It was shown that we can exceed all the given parameters and therefore meet our goals. Especially interesting is the ability to generate a constant temperature output for over one hour. With all the experiments done so far, more than 20 circuits have been completed. In the future, more experiments will follow to show the cycling stability of the storage. Furthermore, there will be experiments with the fuel 
cell to prove the concept and show the ability to operate it with the help of the storage.

\section{ACKNOWLEDGMENT}

The German Federal Ministry for Economic Affairs and Energy has funded this work in the framework of the eleMeMe project (0324026A).

\section{REFERENCES}

[1] A. Hauer, S. Hiebler and M. Reuß, Wärmespeicher, Stuttgart: Fraunhofer IRB Verlag, 2013.

[2] L. F. Cabeza, G. Svensson, S. Hiebler and H. Mehling, "Thermal performance of sodium acetate trihydrate thickened with different materials as phase change energy storage material," Applied Thermal Engineering, vol. 23, pp. 1697-1704, 2003.

[3] G. A. Lane, "Phase change materials for energy storage nucleation to prevent supercooling," Solar Energy Materials and Solar Cells, vol. 2, pp. 135-160, 1992.

[4] F. C. Porisini, "Salt hydrates used for latent heat storage: Corrosion of metals and reliability of thermal performance," Solar Energy, vol. 2, pp. 193-197, 1988.

[5] X. Xiao, P. Zhang and M. Li, "Experimental and numerical study of heat transfer performance of nitrate/expanded graphite composite PCM for solar energy storage," Energy Conversion and Management, pp. 272-284, 2015.

[6] J. Pereira da Cunha and P. Eames, "Thermal energy storage for low and medium temperature applications using phase change materials - A review," Applied Energy, pp. 227-238, 2016.

[7] D. Rozanna, T. G. Chuah, A. Salmiah, T. S. Y. Choong and M. Sa'ari, "Fatty Acids as Phase Change Materials (PCMs) for Thermal Energy Storage: A Review," International Journal of Green Energy, vol. 4, pp. 495513, 2005.

[8] E. P. del Barrio, A. Godin, M. Duquesne, J. Daranlot, J. Jolly, W. Alshaer and T. Kouadio, "Characterization of different sugar alcohols as phase change materials for thermal energy storage applications," Solar Energy Materials and Solar Cells, pp. 560-569, 2017.

[9] P. Kauranen, K. Peippo and P. D. Lund, "An organic PCM storage system with adjustable melting temperature," Solar Energy, vol. 5, pp. 275-278, 1991.

[10] G. Canik and C. Alkan, "Hexamethylene dilauroyl, dimyristoyl, and dipalmytoyl amides as phase change materials for thermal energy storage," Solar Energy, vol. 4, pp. 666-672, 2010.

[11] Paraffin - an Overview [Working Title], IntechOpen, 2019.

[12] S. Karaman, A. Karaipekli, A. Sarı and A. Biçer, "Polyethylene glycol (PEG)/diatomite composite as a novel form-stable phase change material for thermal energy storage," Solar Energy Materials and Solar Cells, vol. 7, pp. 1647-1653, 2011.
[13] C. Zauner, F. Hengstberger, M. Etzel, D. Lager and R. Hofmann, "Experimental characterization and simulation of a fin-tube latent heat storage using high density polyethylene as PCM," Applied Energy, pp. 237-246, 2016.

[14] Y. Tang, D. Su, X. Huang, G. Alva, L. Liu and G. Fang, "Synthesis and thermal properties of the MA/HDPE composites with nano-additives as form-stable PCM with improved thermal conductivity," Applied Energy, pp. 116-129, 2016.

[15] J. Li, P. Xue, W. Ding, J. Han and G. Sun, "Microencapsulated paraffin/high-density polyethylene/wood flour composite as form-stable phase change material for thermal energy storage," Solar Energy Materials and Solar Cells, vol. 10, pp. 1761-1767, 2009.

[16] R. M. S. R. J. Waschull, "Investigation of phase change materials for elevated temperatures".

[17] M. Joemann, T. Oezcan, M. Kauffeld and C. Pollerberg, "Process Steam and Chilled Water Production with CPC-collectors, Steam Jet Ejector Chiller and Latent Heat Storages," Energy Procedia, pp. 767-776, 2016.

[18] H. M. Weingrill, K. Resch-Fauster, T. Lucyshyn and C. Zauner, "Thermally conductive high-density polyethylene as novel phase-change material: Application-relevant long-term stability," J. Appl. Polym. Sci. (Journal of Applied Polymer Science), pp. 48269, 2020.

[19] R. Bayón, E. Rojas, L. Valenzuela, E. Zarza and J. León, "Analysis of the experimental behaviour of a $100 \mathrm{kWth}$ latent heat storage system for direct steam generation in solar thermal power plants," Applied Thermal Engineering, vols. 17-18, no. 30, pp. 2643-2651, 2010.

[20] F. Fornarelli, S. M. Camporeale, B. Fortunato, M Torresi, P. Oresta, L. Magliocchetti, A. Miliozzi and G. Santo, "CFD analysis of melting process in a shell-andtube latent heat storage for concentrated solar power plants," Applied Energy, pp. 711-722, 2016.

[21] V. Zipf, A. Neuhäuser, D. Willert, P. Nitz and S Gschwander, "High temperature latent heat storage with a screw heat exchanger: Design of prototype," Applied Energy, pp. 462-469, 2013.

[22] DeBoer, "Heat storage systems for use in an industrial batch process: (results of) a case study".

[23] A. M. S. Senthur Prabu, "A study of waste heat recovery from diesel engine exhaust using phase change material," International Journal of ChemTech Research, vol. 8, pp. 711-717, 2015.

[24] K. Nagano, K. Ogawa, T. Mochida, K. Hayashi and H. Ogoshi, "Performance of heat charge/discharge of magnesium nitrate hexahydrate and magnesium chloride hexahydrate mixture to a single vertical tube for a latent heat storage system," Applied Thermal Engineering, pp. 209-220, 2004. 
[25] Peter Huber Kältemaschinenbau AG, "Thermofluide / Heat Transfer Fluids," [Online]. Available: https://www.huberonline.com/download/brochures/Huber_Thermofluids_ 2019. [Accessed 04.03.2020].

[26] Deutsche Edelstahlwerke GmbH, "Werkstoffdatenblatt X2CrNiMo17-12-2 1.4404," 08.06.2016. [Online]. Available: https://www.dewstahl.com/fileadmin/files/dewstahl.com/documents/Publikationen/Werkstoffdatenbla etter/RSH/1.4404_de. [Accessed 04.03.2020].
[27] Deutsche Edelstahlwerke $\mathrm{GmbH}$, "Werkstoffdatenblatt X5CrNi18-10 1.4301," 27.11.2015. [Online]. Available: https://www.dew-stahl.com/fileadmin/files/dewstahl.com/documents/Publikationen/Werkstoffdatenbla etter/RSH/1.4301_de. [Accessed 04.03.2020].

[28] Rockwool Technical Insulation, "Rockwool Produktkatalog Preisliste 2019," 01.02.2019. [Online]. Available: http://daemmtherm.de/wpcontent/uploads/Kataloge/Rockwool\%20Technische\%2 OIsolierung. [Accessed 04.03.2020]. 